Studia Anglica Posnaniensia 52(1), 2017

doi: 10.1515/stap-2017-0001

\title{
"WHEN THAT WOUNDS ARE EVIL HEALED": REVISITING PLEONASTIC THAT IN EARLY ENGLISH MEDICAL WRITING
}

\author{
JAVIER CALLE MARTín ${ }^{*}$
}

Universidad de Málaga

\begin{abstract}
$^{1}$
The origin of pleonastic that can be traced back to Old English, where it could appear in syntactic constructions consisting of a preposition + a demonstrative pronoun (i.e., for py pat, for paem pe) or a subordinator (i.e., op pat). The diffusion of this pleonastic form is an Early Middle English development as a result of the standardization of that as the general subordinator in the period, which motivated its use as a pleonastic word in combination with many kinds of conjunctions (i.e., now that, if that, when that, etc.) and prepositions (i.e., before that, save that, in that) (Fischer 1992: 295). The phenomenon increased considerably in Late Middle English, declining rapidly in the 17th century to such an extent that it became virtually obliterated towards the end of that same century (Rissanen 1999: 303-304). The list of subordinating elements includes relativizers (i.e., this that), adverbial relatives (i.e., there that), and a number of subordinators (i.e., after, as, because, before, beside, for, if, since, sith, though, until, when, while, etc.).

The present paper examines the status of pleonastic that in the history of English pursuing the following objectives: (a) to analyse its use and distribution in a corpus of early English medical writing (in the period 1375-1700); (b) to classify the construction in terms of genre, i.e., treatises and recipes; and (c) to assess its decline with the different conjunctive words. The data used as source of evidence come from The Corpus of Early English Medical Writing, i.e., Middle English Medical Texts (MEMT for the period 1375-1500) and Early Modern English Medical Texts (EMEMT for the period 1500-1700). The use of pleonastic that in medical writing allows us to reconsider the history of the construction in English, becoming in itself a Late Middle English phenomenon with its progressive decline throughout the 16th and 17th centuries.
\end{abstract}

* Universidad de Málaga, Departamento de Filología Inglesa, Francesa y Alemana, Facultad de Filosofía y Letras, Campus de Teatinos s/n, Málaga 29071, Spain. Email: jcalle@uma.es

1 The present research has been funded by the Ministry of Economy and Competitiveness (grant number FFI2014-57963-P), and by the Autonomous Government of Andalusia (grant number P11-HUM7597). I am particularly grateful to Prof. Matti Rissanen (University of Helsinki, Finland) for the information he provided on the Old Norse influence on the phenomenon. 
Keywords: Early Modern English; historical syntax; medical writing; Middle English; pleonastic that.

\section{Introduction}

Derived from the Greek term $\pi \lambda \varepsilon o v \alpha \sigma \mu$ ó $s$ 'superabundance, excess', a pleonasm is used in linguistics to denote a particular type of redundant linguistic expression, either as a fault of style, or as a figure purposely used for special force or clearness (OED s.v. pleonasm, n.). In many cases, these pleonasms function as a rhetorical repetition in search of a specific linguistic effect, where the redundancy can be dropped with no loss of meaning. Pleonasms can be syntactic (i.e., I know that she will be here soon, the reason is because) or strictly semantic (i.e., a free gift, a true fact, aches and pains, null and void, tuna fish, at 12 midnight, etc.). ${ }^{2}$

The phenomenon has been differently labelled in the literature, from hyperdetermination (Malkiel 1957: 79) to hypercharacterization (Lehman 2005: 119) and overcharacterization (Booij 2007: 273). To my knowledge, the most detailed analysis of the topic is provided by Lehman, who classifies pleonasms at different levels of linguistic analysis. In the light of his categorization, the phenomenon is classified into tautology (i.e., one constituent is synonymous with the other), stylistic pleonasm (i.e., pragmatically motivated), and hypercharacterization (i.e., grammatically motivated), regardless of whether it responds to semantic or morpho-syntactic motivations (2005: 119). ${ }^{3}$

The use of pleonastic that in the history of English can be safely ascribed to Lehman's category of hypercharacterization according to which the general subordinator that becomes spuriously added to all kinds of conjunctions and prepositions (Fischer 1992: 295), as in examples (1-2).

(1) and y beleue zif that he wyl take hede to alle [...] (MEMT, Lanfranc, Chirurgia magna 2).

2 The emphatic element of pleonasms turns them into a recurrent device in many languages. Spanish, among others, count on instances such as subir para arriba, bajar para abajo, el día martes, el mes de septiembre, hoy en dia, hoy por hoy, etc. In French, the most typical example is the use of the word pas with the negative adverb ne for strictly emphatic purposes, as in Je ne suis pas riche 'I am not rich' (Wigdorsky 2004: 171-178; also Iglesias-Casal 1989: 118-122).

3 The term overcharacterization is elsewhere considered to be more lexically-oriented to refer to the addition of a superfluous suffix in the coining of a new word, while the terms hyperdetermination and hypercharacterization have a morpho-syntactic bias (Gardani 2015: 538). 
(2) The man that is borne while that the Moon enters in this sign (EMEMT, Moulton, Myrrour or Glasse of Helth Astrology, 1539).

The origin of the phenomenon can be traced back to the Old English prepositional conjunctions, i.e., those syntactic groups consisting of a prepositional element, an oblique form of the demonstrative pronoun paet along with the particle be or poet, in cases like for py paet, for poem be, to pon pact, etc., the last element considered as optional (Mitchell 1985: §2420; Rissanen 1997: 374). By the end of the Old English period, the second and third elements of prepositional conjunctions began to weaken until their progressive obliteration, to such an extent that the third element was generally replaced by pat, appended as a marker of subordination even to conjunctions with which it did not appear in Old English, prepositions also included, such as before that, save that, in that (Beal 1988: 60). Even though its use considerably increased throughout the Late Middle English period, the construction reached its climax in the 16th century, declining progressively in the course of the following century (Rissanen 1999: 303-304).

Different interpretations account for the development of the construction in Middle English, one considering it as a native and the other as a non-native phenomenon. The rise of pleonastic that, on the one hand, is viewed as the result of its standardization as the general subordinator in Middle English, the list including nominal, adjectival, and particular types of adverbial clauses. Rissanen argues that "the need for this kind of marker was created by the collapse of the Old English subordinating groups $[\ldots]$ and the increase in the number and variety of subordination" (1997: 375). The heterogeneous nature of the subordinator that plausibly contributed to its extension to other types of subordinate clauses where it was not strictly necessary, becoming a frequent form in the latter part of Middle English (Kivimaa 1966: 248; Fischer 1992: 295). ${ }^{4}$

Its origin, on the other hand, has also been conceived from the point of view of a language contact situation as a result of a likely Scandinavian influence (Rissanen 1997: 379; 1999: 303; also Kivimaa 1966: 255-256). Old Norse at could be used pleonastically in the same way as the earlier English that in a construction like ef at 'if that' and, moreover, similar constructions are still used in some Scandinavian languages. ${ }^{5}$ Even though the Old Norse impulse may

4 Even though more difficult to justify, the collapse of the verb-final word order, another subordination marker in Old English, could have also indirectly contributed to the proliferation of pleonastic that after the Norman conquest (Rissanen 1997: 375).

5 This use is mentioned in A Dictionary of Old Norse Prose giving an example of the phrase ef at introducing a subordinate clause. This pleonastic use of at is also included in the glossary of Gordon's Introduction to Old Norse (1957), providing references to text passages. 
have played an important role in the incipient stages of the development, it cannot be overestimated in the light of the diffusion of the phenomenon in early South West Midland texts (Rissanen 1997: 379).

Regardless of its native or non-native origin, it is also a fact that the particular requirements of metre could have also paved the way to its standardization in Middle English. Pleonastic that is many a time used as a line filler to provide metrical regularity, a fact which explains why it is a device twice as common in Chaucer's verse than in his prose (Kivimaa 1968: 48-49, 70-71). Notwithstanding this, pleonastic and non-pleonastic that are not, however, clearly distinguished in Chaucer, eventually producing the unconscious incorporation of this spurious element in his prose (Brinton 1996: 352; also Putter, Jefferson \& Stokes 2007: 135).

In our opinion, however, there is still an important gap in the field, especially from a historical viewpoint since the phenomenon has been mostly discussed synchronically in Late Middle English, Chaucer's verse in particular (Kivimaa 1966). In Early Modern English, this pleonasm has been studied in the light of the data provided by the Helsinki Corpus of English Texts, where Rissanen concludes that, even though a Late Middle English innovation, it is observed to be a 16th-century development of English (1989: 3-18; 1997: 373383). The present paper then reconsiders the origin, development and decline of pleonastic that from a diachronic perspective in the light of The Corpus of Early English Medical Writing in the historical period of 1375-1700.

Medical writing is free from the artificiality of verse compositions and may be a reliable source of evidence on many morpho-syntactic changes in the history of English. By the year 1475, the first phase of the vernacularization of scientific and medical writing was largely complete, to such an extent that the use of the vernacular became even more common than Latin for the rendering of scientific material (Voigts 1996: 816; Pahta \& Taavitsainen 2004: 12; Taavitsainen \& Pahta 1998: 159). Shaped under the shelter of the Greco-Roman models, Latin together with French served as the main sources for vernacular translations in Late Middle and Early Modern English (Siraisi 1990: 53; 2010: 256). Remedy books, on the contrary, were still oriented towards a more popular audience, thus continuing the Old English tradition and being less influenced by classical patterns of writing. The second and third phases of vernacularization span from 1475 to 1550 and from 1550 to 1700 , respectively, ${ }^{6}$ and it was precisely in this last stage when the supremacy of Latin ceased in favour of English, partially influenced by the publication of Philosophical Transactions in the vernacular.

6 Taavitsainen proposes 1475 as the beginning of the second phase of vernacularization coinciding with the introduction of the printing press in England (2012: 98). 
In the absence of a national standard for scientific communication, the process of the vernacularization of science may cast some light on the origin and development of different linguistic changes in the history of English. In the light of this assumption, the present paper has been conceived with the following objectives: (a) to analyse the distribution of pleonastic that in a corpus of early English medical writing (1375-1700); (b) to classify the construction in terms of the different types of medical texts; and (c) to assess the decline of the construction throughout the Early Modern English period.

\section{Methodology}

The data used come from two sections of the Corpus of Early English Medical Writing: Middle English Medical Texts (henceforth MEMT), for the historical period 1375-1500, and Early Modern English Medical Texts (henceforth EMEMT), for the period 1500-1700. These corpora have been chosen both on quantitative and qualitative grounds. In quantitative terms, they amount to more than 1.8 million words, which is a sizeable input for an analysis of this type of construction. From a qualitative perspective, in turn, the Corpus of Early English Medical Writing is organised into three main branches: specialised treatises, surgical treatises, and recipe collections, the latter being of a more colloquial nature (Pahta \& Taavitsainen 2004: 7). ${ }^{7}$

MEMT contains more than half a million words based on both edited medical texts and early printed books from 1375 to 1500 . The bulk of these treatises are translations from Latin, dealing with a wide variety of topics, such as ophthalmology, gynaecology, urinoscopy, phlebotomy, epilepsy, syphilis, and the plague (Méndez-Naya \& Pahta 2010: 193). EMEMT is a two-millionword corpus of medical writing for the period 1500-1700 covering "the full range of printed medical writing in the Early Modern period, with its rich diversity" (Taavitsainen \& Tyrkkö 2010a: 57). Following the Late Middle English component, EMEMT is divided into (a) general treatises and treatises on specific topics; (b) surgical and anatomical treatises; and (c) recipe collections and materia medica together with health guides (Taavitsainen \& Tyrkkö 2010b: 65-66; Pahta \& Ratia 2010: 73-74; Marttila 2010: 102-103; Tyrkkö 2010: 119-120). For comparison, the EMEMT material has been classified into four fifty-year sub-periods based on the year of printing indicated in the sources. Table 1 reproduces the word count for the source data. ${ }^{8}$

7 The Corpus of Early English Medical Writing also includes a small selection of verse texts, $M E M T$ in particular. These verse texts, however, have not been considered in this study, assuming that the artificiality of these compositions could have, to a certain extent, blurred the actual distribution of the phenomenon in prose material.

8 General treatises or textbooks provide a systematic account of the whole field of medicine; 
Table 1. Word count for MEMT and EMEMT

\begin{tabular}{lrrrrr}
\hline Corpus & & $\begin{array}{c}\text { Specialized } \\
\text { texts }\end{array}$ & $\begin{array}{c}\text { Surgical } \\
\text { texts }\end{array}$ & Remedies & Total \\
\hline$M E M T$ & $1375-1500$ & 88,349 & 137,794 & 219,395 & 445,538 \\
EMEMT & $1500-1700$ & 762,667 & 298,352 & 339,068 & $1,400,087$ \\
EMEMT1 1500-1549 & 59,602 & 21,910 & 46,814 & 128,326 \\
EMEMT2 & $1550-1599$ & 162,313 & 102,919 & 92,405 & 357,637 \\
EMEMT3 $1600-1659$ & 228,135 & 50,771 & 71,047 & 349,953 \\
EMEMT4 1650-1700 & 312,617 & 122,752 & 128,802 & 564,171 \\
\hline
\end{tabular}

AntConc (version 3.4.3) has been used for the automatic retrieval of the instances. The process, however, was not straightforward in view of the particulars of the corpora. As a tagged version of MEMT is not hitherto available, the present research was based on the plain text version of the corpus. For convenience, the complete concordances for that were generated and sorted according to the preceding context. This facilitated the disambiguation of the instances in such a way that the instances without a preceding conjunction could be easily discarded. As for EMEMT, on the other hand, the normalized version of the corpus was processed. Thus, the spelling normalization of the Early Modern English component of the corpus allowed us to retrieve all the instances of pleonastic that automatically, just by prompting the particular conjunction involved.

The present study is restricted to the analysis of pleonastic that in relative clauses (i.e., which and who) and the following subordinators (i.e., afore, after, as, because, before, beside, for, if, since, sith, though, until, what, when, where, while, why, etc.). The process, however, was not straightforward inasmuch as there were instances in which that did not appear in pleonastic use, either as a deictic demonstrative or as a conjunction introducing a that-clause, as shown in examples (3-4). The disambiguation process thus trimmed down the corpus instances to a total of 1,600 instances, 602 in MEMT and 998 in EMEMT.

treatises on specific topics are texts on particular diseases and concrete methods of diagnosis or treatment, on specific therapeutic substances, on midwifery and children's diseases, and on the plague; recipe collections and materia medica contain both remedy books and formalized pharmacopoeias; regimens and health guides comprise texts on preventive medicine; surgical and anatomical treatises constitute treatises on surgery and anatomy; and Philosophical Transactions consists exclusively of medical texts published as letters or articles in the Philosophical Transactions of the Royal Society embodying the state of scientific writing after the transition from a scholastic to an empirical thought-style (Taavitsainen \& Pahta 2011: 22-25; see also Gotti 2001; Taavitsainen 2002). Given that there is no counterpart in the Middle English component of the corpus, Philosophical Transactions has been ruled out from our study. 
(3) $[\ldots]$ be it so known that this or that medicine, hath virtue to fill an hollow (EMEMT, Galen, Methodus Medendi, 1586).

(4) Neither is it to be doubted but that these humours doe move (EMEMT, Brugis, Marrow of Physicke, 1640).

\section{Analysis}

\subsection{Quantitative analysis}

The present section assesses the distribution of the phenomenon across time in the historical period of 1375-1700. Figure 1 reproduces the total of instances both in raw and normalized frequencies (to tokens per 10,000 words). The use of pleonastic that is well diffused in Late Middle English with a distribution of 135.12 instances in MEMT. It then declined throughout the 16th century, decreasing to 80.65 and 91.39 instances in-between 1500-1549 and 1550-1599, respectively. In the 17th century it remains as an optional variant, losing its productivity from the second half of that same century, amounting to just 33.67 occurrences in the last sub-period, one third of the instances found in the previous century.

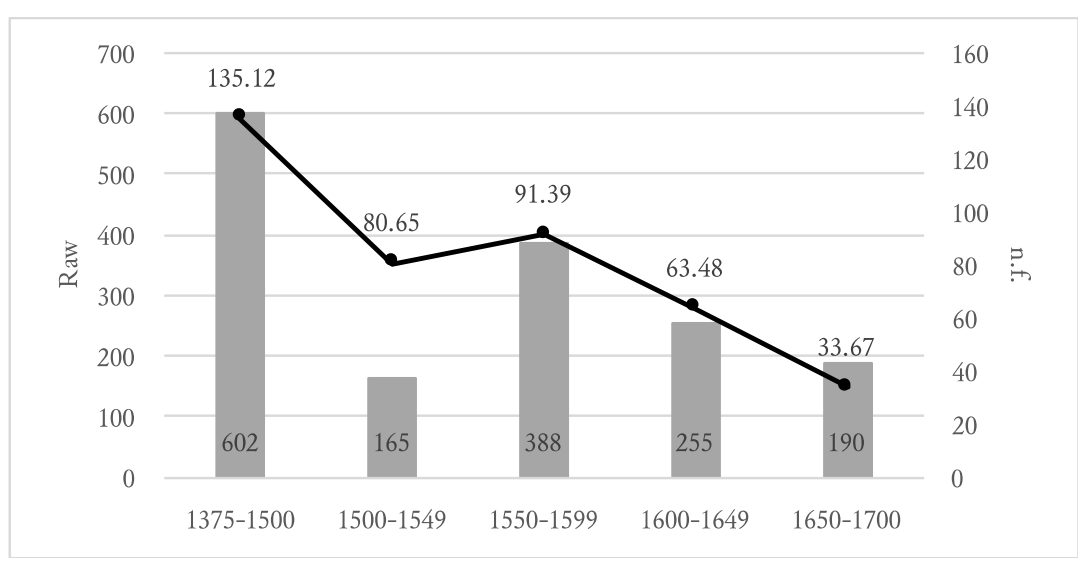

Figure 1. Distribution of pleonastic that across time (raw and n.f.)

The distribution obtained from The Corpus of Early English Medical Writing does not tally with the occurrence of the phenomenon in other typology of texts. In his analysis of The Helsinki Corpus of English Texts, Rissanen describes the actual spread of the phenomenon in the 16th century with a decreasing popularity in the 17th century, its use stretching until the beginning of the 
following century (Rissanen 1999: 303). Medical writing, however, allows us to date its climax in Late Middle English, a preference plausibly associated with the recurrent use of pleonastic that with the subordinators for and if, especially if compared with other conjunctive words.

The Corpus of Early English Medical Writing also allows us to classify the construction in terms of the different text types, i.e., specialized texts, surgical texts, and remedies. These genres represent different registers within the field of medical writing. Thus, while theoretical treatises are considered the most academic register, remedies portray the language used by lay people, as they were a collection of recipes that families stored for their use at home. Surgical treatises, in turn, would fall in-between the above-mentioned classes.

Figure 2 reproduces the distribution of pleonastic that across the different text types (also normalized to tokens per 10,000 words). In MEMT, on the one hand, it diffuses more substantially in surgical treatises (with 260.53 occurrences), followed by theoretical treatises (with 235.43 occurrences). More important, however, is the constrained distribution of the phenomenon in remedies, where its use decreases to just 15.95 occurrences. This fact casts some new light on the development of the construction in the latter part of Middle English. Remedy books can be traced back to the Old English period, and consist of treatments for ailments written by non-practitioners based on "adaptation and accretion", ultimately devised for the use of laymen and academic physicians (Voigts \& McVaugh 1984: 21). Theoretical and surgical treatises, in turn, were new in the Middle English period and belonged to the learned tradition, being mostly translations of learned Latin medicine with an academic origin designed for physicians of the highest class, surgeons, and barber surgeons. ${ }^{9}$ Their different traditions of writing and intended readership may, to a certain extent, justify the heterogeneous treatment of pleonastic that in these texts.

Taavitsainen refers to the problematic position of surgical treatises in Voigts \& McVaugh's taxonomy (1984). Even though they also belong to the academic tradition, these texts mostly originate in learned circles, having a place among practical sciences as well (Taavitsainen \& Pahta 1997: 74). 


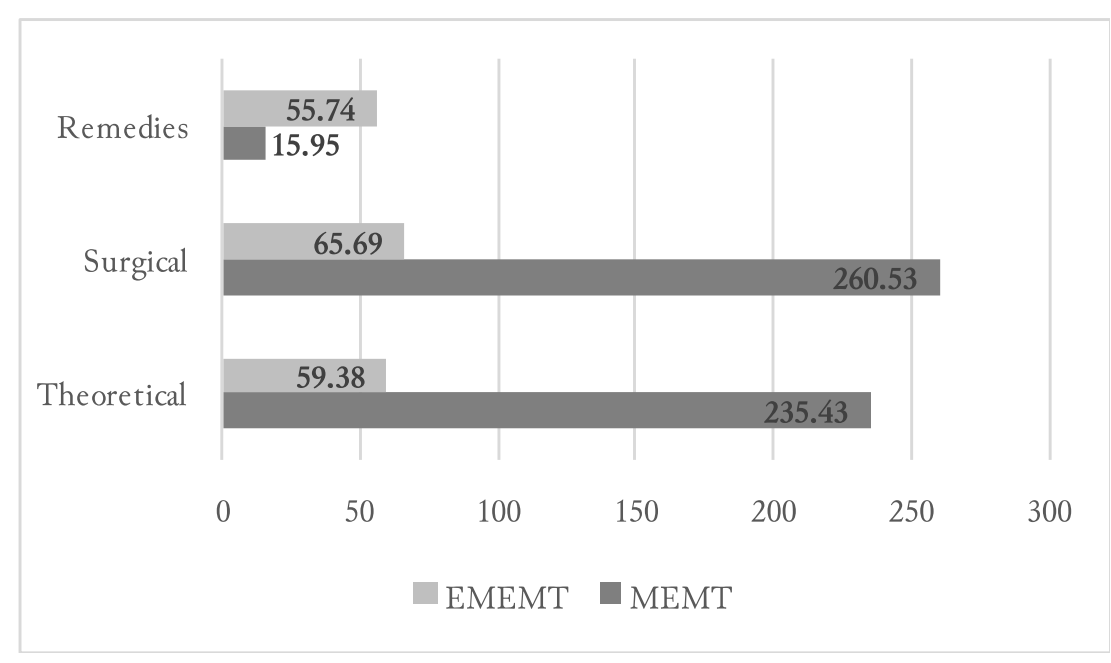

Figure 2. Distribution of pleonastic that across text types (n.f.)

As shown, the construction proliferates in translated material composed for the learned circles, as a kind of hypercorrected form incorporated as a result of the vernacularization of science through the transfer of the Latin and French models. In the English version of Jean Liébault's Trois Libre Appartenans aux Infirmitez et Maladies des Femmes, for instance, the translator every now and then opts for the use of pleonastic that mirroring the French conjunction que. In example (5) the English translator renders after that because of the use of the sequence apre que in the French original, thus replicating the two-element subordinating conjunction. Even though this cannot be considered a systematic practice among Late Middle English and Early Modern English translators, it could have certainly promoted the diffusion of the phenomenon under the shelter of the vernacularization of medical texts. Remedies, on the contrary, are free from the above-mentioned artificiality of learned compositions, and consequently they do not make enough room for this pleonastic item, especially in the period 1350-1500 when it was still incipient, plausibly because the phenomenon had a constrained role in the spoken domain.

(5a) Le meilleur de tous pour purger par bas, est le cotignac de Lyon, aquel on aura adioutté quelque peu de myrobalans citrins puluerisez. Apres que l'bumeur fera purgé, pour conforter l'estomach, $\&$ astreindie de plus en plus son orifice superieur (Jean Liébault, Trois Libre Appartenans aux Infirmitez et Maladies des Femmes, 1585, p. 21, chapter X). 
(5b) The best of all to purge downward is the marmellade of quinces of Lion, whereunto hath been added a litle myrobolans citrins brought to poulder. After that the humour hath been purged, to comfort the stomack and bind the vpper mouth (Treatise of the Diseases of Women, GUL 303, 17th-century).

The EMEMT component, on the other hand, presents a significant increase of the phenomenon in remedies with 55.74 occurrences, especially if compared with the Late Middle English distribution, while surgical and theoretical treatises still pioneer the use of the construction with a total of 65.69 and 59.38 occurrences. These figures, however, cannot be overestimated as they lead us to obtain some evidence on the status of pleonastic that throughout the 16th century. Even though it is a fact that its use declines in the learned compositions, its rise in recipes tentatively confirms Rissanen's point that it spread in the 16th century reaching its climax towards the end of that same century (Rissanen 1999: 303). The distribution of pleonastic that in recipes then confirms that this hypercorrected form was experiencing an on-going process of diffusion, not only in the written compositions of the learned circles, but more importantly in the more popular text types, thus corroborating that it was also finding room in the spoken domain.

\subsection{Qualitative analysis}

This section explores the distribution of pleonastic that from a qualitative standpoint to evaluate the development and decline of the phenomenon across particular subordinators. Figure 3 reproduces the distribution of the constructions after that, as that, because that, but that, for that, and if that over time according to the five sub-periods proposed by MEMT and EMEMT, the figures also normalized to a text of 10,000 words for comparison. These subordinators have been chosen in view of their higher occurrence in the corpus.

The phenomenon is observed to diffuse differently with particular types of conjunctions. In Late Middle English, it is mostly triggered in combination with conditional clauses introduced by if, amounting to 37.48 occurrences. Next, this pleonasm is also observed to appear in the subordinate clauses of time introduced by after (with 23.79 occurrences), when (with 15.49 instances), and until (with 10.77 instances). Finally, the frequency of for that is also widespread with 11.9 occurrences. Examples (6-8) present the use of pleonastic that in combination with the subordinators if, after, when, and whether, respectively.

(6) Do make pis water Take maydenhere and pe rote of borage and pe rote of paritorie and pe rote of hertestong and pe rotes forsayd do sepe hem to pe 
halfendel and pan do streyne pis licour and mak pe seek drenk ate morne .iij. sponful Now it is to touche zif pat pe splen be yswolle (MEMT, Cophon, Experimentes).

(7) Bot wytte pou pat in clistrying pe leche owe for to augmente and lessen pe proporcion of salt after pat pe vertu of pe pacient may thole, suffre, for pe tendernes of longaon, and after bat he sepe pe pacient strong, softe or hard for to avoiden. ffor grete quantite of salt makep sone pe clistery for to haste to be goyng out (MEMT, Arderne, Clysters).

(8) And ziff a man knowe pe pocicioun oper settinge and pe making pe nature oper be kinde in euery partikel in alle a mannes bodie, pen he maye liztlye knowen when pat a man is hurte, in what place of pe bodie pat euer he be hurte, whepir pat per be sinewe oper brawne oper corde oper ligament touched (MEMT, Chauliac, Anatomy Interpolated).

The Early Modern period, however, shows a different state of affairs. The frequency of the construction substantially decreases in combination with the conditional subordinator if, and the phenomenon is mostly triggered in combinations such as for that, together with as that and after that, as shown in examples (9-11). In addition to this, there is also the widespread use of that with other conjunctions, this being the case of the coordinators but that and or that and after wh-words, where and when in particular. The relativizers which and who, in turn, are observed to be sporadically used in combination with this pleonasm.

(9) I am not ignorant that diuers later writers do constantly affirme that in this our time we cannot make either good Theriacle or good Mithridatium, for that they say we do lacke many simples going into their compositions, [...] (EMEMT, Bailey, Mithridatium, 1585).

(10) But besides the fastenyng, that they haue in the iawes, in dryed bodies: in creatures yet liuyng, they are also clothed aptly with flesh about their rootes and contract, and filled on eche side with gowmes, which flesh is made so callous, and indurated, as that the teeth thereby are not a little delited, and bowlstred (EMEMT, Banister, Historie of Man, 1578).

(11) And that the Anatomie of membres contained in the head might be more euidently declared, it is profitable after that ye haue taken awaye ye flesche of the sculle, \& of the eyebrowes to diuide the brayne panne with a sawe circularely (EMEMT, DeVigo, Most Excellent Workes of Chirurgerye, 1543).

Our results tentatively allow us to date the decline of pleonastic that in the light of the development of particular subordinators across time. After the spread of 
the phenomenon in the Middle English period, it was in use until the end of the 16th century in after that, because that, but that, for that, and if that in particular. The beginning of the 17th century witnesses its progressive decline to such an extent that it is considerably reduced to less than five occurrences in cases such as after that (3.24 instances), because that (3.98 instances), but that (4.98 instances), and if that (1.99 instances).

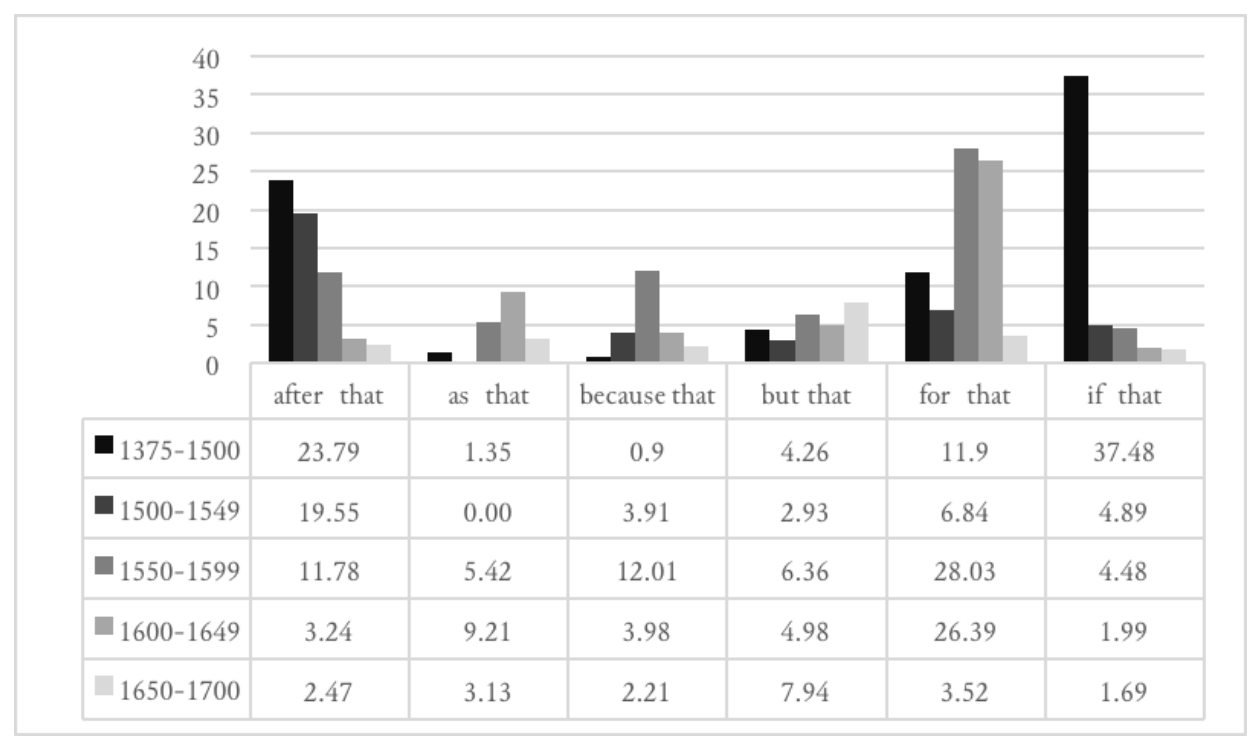

Figure 3. Development of some pleonastic combinations across time (n.f.)

Notwithstanding this, its decline is not systematic since particular constructions are observed to be more reluctant to disappear, extending well into the 17th century. This is particularly the case of the construction for that, which is found to be actively used until the second part of the 17th century, with 26.39 occurrences in-between 1600-1649 and 3.52 instances in-between 1650-1700. The proliferation of for that when all the other pleonastic forms of that were becoming obsolete has been associated with the movement of for towards a coordinator, sharing both coordinator and subordinator characteristics. As a result of this shift, "the formal marking of the subordinator use of this conjunction by that temporarily gained in importance" (Rissanen 1989: 14; also Beal 1988: 63). At the end of the 17th century, for that was practically the only conjunction of its type, which eventually resulted in its disappearance. A similar tendency is observed with the coordinate conjunction but that, which amounts to 4.98 and 7.94 occurrences in the periods $1600-1649$ and $1650-1700$, respectively. 
The decline of pleonastic that cannot then be understood as a uniform and homogeneous process in the history of English. Even though the downfall initiates towards the first half of the 17th century, there are particular subordinators which show an active use throughout the second half of that same century, declining approximately 50 years later. These combinations, therefore, are found not to be equally conceived in the mind of speakers in the sense that they have plausibly developed a fossilized status, treated as a single subordinator. These cognitive associations therefore justify the longer process of obliteration, lagging considerably behind the other pleonastic constructions in the history of English.

The preservation of these fossilized combinations in medical writing until the end of the Early Modern period can be associated with the intrinsic features of this type of writing. The on-going process of vernacularization in the period together with the influence of the translation process could have imprinted stylistic conservatism together with a higher level of formality. This same justification accounts for the wider distribution of the phenomenon in more academic compositions.

\section{Conclusions}

The present paper has investigated the use of pleonastic that in a corpus of Late Middle English and Early Modern English medical writing, paying particular attention to its distribution both across time (1375-1700) and across the different textual categories in terms of the traditional classification into general treatises, specialized treatises, and remedies. The study is based on a complete set of pleonastic combinations in The Corpus of Early English Medical Writing, which provides us with a total of 1,600 instances of the construction, of which 602 and 998 correspond to Late Middle English and Early Modern English, respectively.

Our study, on the one hand, dates the origin and actual spread of the phenomenon in the Late Middle English period. The picture obtained from medical writing, however, differs from previous accounts of the phenomenon with other text types, suggesting that it overwhelmingly disseminates in this type of material in the 15th century, declining slightly throughout the 16th century until its progressive obliteration in the course of the following century. ${ }^{10}$

10 The disappearance of this pleonasm can be chronologically connected, to a certain extent, with the decline of other pleonastic constructions in the history of English, such as pleonastic pronouns, pleonastic comparatives and superlatives, or the expletive negative adverb ne. The progressive rejection of these superfluous constructions was in many cases accelerated by the emergence of the standard syntactic pattern subject + verb + object, especially from Late Middle English and extending well into the Early Modern English period. 
More importantly, the phenomenon has also been investigated in terms of the traditional categorization of medical writing into remedies, surgical, and theoretical treatises. While its use becomes a recurrent feature in both surgical and theoretical treatises, its frequency was found to be erratic in remedies, and considered to be less artificial than the other categories. This fact sheds new light on the likely origin and impulse of the phenomenon in the history of English insofar as this pleonasm is observed to disseminate more frequently in translated material composed for learned physicians, surgeons, and barber surgeons, plausibly as examples of hypercorrection in the attempt to provide a higher status to these compositions. Remedies, in turn, are less prompt to allow such constructions, plausibly as a result of their constrained role in the spoken domain, Middle English in particular.

Finally, our study also revealed that the decrease of pleonastic that cannot be understood as a homogeneous process in the history of English in the sense that it is not systematic across all the subordinators. Contrariwise, there are particular combinations that were found to be actively in use throughout the second half of the 17th century, thus declining approximately fifty years later than other pleonastic subordinators. This is particularly the case of for that and, to a lesser extent, but that, perhaps as a result of their fossilized status in Early Modern English.

\section{REFERENCES}

Beal, Joan. 1988. Goodbye to all 'that'? The history and present behaviour of optional 'that'. In Graham Nixon \& John Honey (eds.), An historic tongue: Studies in English linguistics in memory of Barbara Strang. 49-66. London and New York: Routledge.

Brinton, Laurel. 1996. Pragmatic markers in English. Grammaticalization and discourse functions. Berlin and New York: Mouton de Gruyter.

Booij, Geert. 2007. The grammar of words. An introduction to linguistic morphology. Oxford: Oxford University Press.

Fischer, Olga. 1992. Syntax. In Norman Blake (ed.), The Cambridge history of the English language. Vol. 2: 1066-1476. 207-408. Cambridge: Cambridge University Press.

Gardani, Francesco. 2015. Affix pleonasm. In Peter O. Müller, Ingeborg Ohnheiser, Susan Olsen \& Franz Rainer (eds.), Word-formation. An international handbook of the languages of Europe. Vol. 1. 537-550. Berlin: Mouton de Gruyter.

Gordon, Eric V. 1957. An introduction to Old Norse. Oxford: Clarendon Press.

Gotti, Maurizio. 2001. The experimental essay in Early Modern English. European Journal of English Studies 5(2). 221-239. doi: 10.1076/ejes.5.2.221.7307

Iglesias-Casal, Isabel. 1989. Sobre los relativos con unidades pronominales ¿redundantes? Contextos 7(14). 111-122. 
Kivimaa, Kirsti. 1966 (1967). The pleonastic that in relative and interrogative constructions in Chaucer's verse. Helsinki: Societas Scientiarium Fennica.

Kivimaa, Kirsti. 1968. Pe and pat as clause connectives in Early Middle English with special consideration of the emergence of the pleonastic pat. Helsinki: Societas Scientiarium Fennica.

Lehman, Christian. 2005. Pleonasm and hypercharacterization. In Geert Booij \& Jaap van Marle (eds.), Yearbook of morphology 2005. 119-154. Amsterdam: Springer.

Malkiel, Yakov. 1957. Diachronic hypercharacterization in Romance. Archivum Linguisticum 9. 79-113.

Marttila, Ville. 2010. Recipe collections and materia medica. In Irma Taavitsainen \& Päivi Pahta (eds.), Early Modern English medical texts. Corpus description and studies. 101-109. Amsterdam: John Benjamins.

Méndez-Naya, Belén \& Päivi Pahta. 2010. Intensifiers in competition. The picture from early English medical writing. In Irma Taavitsainen \& Päivi Pahta (eds.), Early Modern English medical texts. Corpus description and studies. 191-213. Amsterdam: John Benjamins.

Mitchell, Bruce. 1985. Old English syntax. Vols I-II. Oxford: Clarendon Press.

Pahta, Päivi \& Maura Ratia. 2010. Treatises on specific topics. In Irma Taavitsainen \& Päivi Pahta (eds.), Early Modern English medical texts. Corpus description and studies. 73-99. Amsterdam: John Benjamins.

Pahta, Päivi \& Irma Taavitsainen. 2004. Vernacularisation of scientific and medical writing in its sociohistorical context. In Irma Taavitsainen \& Päivi Pahta (eds.), Medical and scientific writing in Late Medieval English. 1-22. Cambridge: Cambridge University Press.

Putter, Ad, Judith Jefferson \& Mira Stokes. 2007. Studies in the metre of alliterative verse. Oxford: The Society for the Study of Mediaeval Languages and Literature.

Rissanen, Matti. 1989. The conjunction 'for' in Early Modern English. Nowele 14. 3-18. doi: 10.1075/nowele.14.01ris

Rissanen, Matti. 1997. Optional that with subordinators in Middle English. In Raymond Hickey \& Stanisław Puppel (eds.), Language history and linguistic modelling: A festschrift for Jacek Fisiak on his 60th birthday. 373-383. Berlin: Mouton de Gruyter.

Rissanen, Matti. 1999. Syntax. In Roger Lass (ed.), The Cambridge history of the English language. Vol. 3: 1476-1776. 187-331. Cambridge: Cambridge University Press.

[OED] Simpson John A. \& Edmund S. C. Weiner (eds.). 1989. The Oxford English dictionary on CD-ROM. 2nd edn. Oxford: Oxford University Press.

Siraisi, Nancy G. 1990. Medieval and early Renaissance medicine. An introduction to knowledge and practice. Chicago and London: The University of Chicago Press.

Siraisi, Nancy G. 2010. History, medicine, and the traditions of Renaissance learning. Ann Arbor: The University of Michigan Press.

Taavitsainen, Irma. 2002. Historical discourse analysis: Scientific language and changing thought-styles. In Teresa Fanego, Belén Méndez-Naya \& Elena Seoane (eds.), Sounds, words, texts and change. Selected papers from 11 ICEHL, Santiago de Compostela, 7-11 September 2000. 201-226. Amsterdam and Philadelphia: John Benjamins.

Taavitsainen, Irma. 2012. Discourse forms and vernacularisation processes in genres of medical writing 1375-1550. In Anneli Aejmelaeus \& Päivi Pahta (eds.), Translation interpretation - meaning. (Studies across Disciplines in the Humanities and Social Sciences 7.) 91-112. Helsinki: Helsinki Collegium for Advanced Studies. 
Taavitsainen, Irma \& Päivi Pahta. 1997. The Corpus of Early English Medical Writing. ICAME Journal 21. 71-78.

Taavitsainen, Irma \& Paivi Pähta. 1998. Vernacularisation of medical writing in English: A corpus-based study of scholasticism. Early Science and Medicine 3(2). 157-185. doi: 10.1163/157338298X00266

Taavitsainen, Irma \& Päivi Pahta. 2011. Medical writing in Early Modern English. Cambridge: Cambridge University Press.

Taavitsainen, Irma \& Jukka Tyrkkö. 2010a. The field of medical writing with fuzzy edges. In Irma Taavitsainen \& Päivi Pahta (eds.), Early Modern English medical texts. Corpus description and studies. 57-61. Amsterdam: John Benjamins.

Taavitsainen, Irma \& Jukka Tyrkkö. 2010b. General treatises and textbooks. In Irma Taavitsainen \& Päivi Pahta (eds.), Early Modern English medical texts. Corpus description and studies. 65-72. Amsterdam: John Benjamins.

Tyrkkö, Jukka. 2010. Surgical and anatomical treatises. In Irma Taavitsainen \& Päivi Pahta (eds.), Early Modern English medical texts. Corpus description and studies. 119-126. Amsterdam: John Benjamins.

Voigts, Linda. 1996. What's the word: Bilingualism in late-medieval England. Speculum 71(4). 813-826. doi: $10.2307 / 2865721$

Voigts, Linda \& Michael R. McVaugh (eds.). 1984. A Latin technical phlebotomy and its Middle English translation. Philadelphia: The American Philosophical Society.

Wigdorsky, Leopoldo. 2004. Algunas dimensiones sobre la redundancia. Onomázein 10. 171178. 